JAN M. MAŁECKI

\title{
OJCA MARIANA KANIORA DROGA DO WIEDZY
}

Ojciec Marian Kanior przyszedł na świat w Rudniku pod Dobczycami małej wsi małopolskiej należącej do starej parafii Dziekanowice. Rodzice jego: Konstanty i Karolina z Kosałków byli wyrobnikami wiejskimi, czyli należeli do najuboższej warstwy społecznej w przeludnionych wsiach dawnej Galicji. Urodził się 29 listopada 1929 r., a na chrzcie nadano mu na cześć Matki Bożej, której święto Niepokalanego Poczęcia przypadało wkrótce, imię Marian. Do szkoły powszechnej chodził od $1936 \mathrm{r}$. do pobliskich Dziekanowic. Była to szkoła I stopnia, tzn. najniżej zorganizowana w 3-stopniowym systemie ówczesnego szkolnictwa podstawowego. Aby więc ukończyć wyższe klasy szkoły powszechnej, musiał kształcić się w odległych o $5 \mathrm{~km}$ Dobczycach. Był to już okres okupacji hitlerowskiej. W $1940 \mathrm{r}$. rodzina została pozbawiona głównego żywiciela: ojciec został wywieziony na roboty do Niemiec. Mały Marian musiał pomagać w pracy matce. Mimo to nie tylko ukończył 7-klasową szkołę w Dobczycach, ale zaraz po klasie szóstej (w 1943 r.) zapisał się na tajne komplety w zespole Dobczyce-Dziekanowice, gdzie do 1945 r. zdołał przerobić materiał 1. i 2. klasy gimnazjalnej (w przedwojennym systemie szkolnym gimnazjum rozpoczynało sie po 6 klasach szkoły powszechnej, klasa siódma przeznaczona była dla dzieci, które nie kształciły się dalej). Wymagało to niemałego wysiłku i świadczyło o zapale do nauki tego chłopca wiejskiego, który po zajęciach w akceptowanej przez okupanta szkole podstawowej (powszechnej) chodził jeszcze na tajne komplety, a po 5-kilometrowej drodze powrotnej do domu, odrabiał lekcje oraz pomagał matce $w$ gospodarstwie.

Tymczasem skończyła się wojna. Ojciec po powrocie z robót przymusowych przeniósł się z rodziną do Krakowa, gdzie udało mu się dostać stała pracę dozorcy kamienicy przy Rynku Głównym 34. Kaniorowie zamieszkali w tym okazałym gmachu o bogatej historii, noszacym nazwe Pałacu Spiskiego (zajmowali jednoizbowe mieszkanie nr 6). 16-letni Marian znalazł się $\mathrm{w}$ wielkim mieście, które wyszło z wojny bez poważnych zniszczeń, zachowało bez większych strat najwspanialsze zabytki przeszłości narodowej oraz święte miejsca kultu religijnego. W pierwszych zaś latach powojennych 
przeżywało okres niezwykłego ożywienia działalności kulturalnej, po tym, gdy znaleźli tu schronienie liczni artyści i intelektualiści z Warszawy, Lwowa $i$ innych miast. Ta specyficzna atmosfera powojennego Krakowa nie mogła nie wpłynąć na kształtowanie się osobowości młodego człowieka. Kanior został przyjęty do klasy trzeciej Państwowego Gimnazjum im. Jana Sobieskiego - jednej z najbardziej prestiżowych szkół średnich Krakowa. Kierując się jednak zapewne względami praktycznymi - uzyskania zawodu, po zdaniu w czerwcu 1946 r. tzw. małej matury (ukończenie czterech klas gimnazjum) przeniósł się do Państwowego Liceum Administracyjnego mieszczącego się przy ul. Kapucyńskiej 2. Tam też w 1948 r. złożył egzamin dojrzałości.

Realizując konsekwentnie swoje zamiary podjął zaraz po maturze studia wyższe. Może zainteresowanie problemami gospodarczymi a z pewnościa i specjalność obrana w liceum skłoniły go do wybrania Akademii Handlowej, wówczas jeszcze szkoły „niepaństwowej”, o przedwojennej strukturze organizacyjnej. Zaczynał się już jednak okres dostosowywania szkolnictwa wyższego w Polsce do nowego ustroju społeczno-politycznego, tzn. narzucania w nauczaniu ideologii marksistowskiej i wzorów radzieckich. Proces ten objął również, a może nawet w pierwszym rzędzie, szkoły ekonomiczne. Krakowska Akademia Handlowa została w 1950 r. upaństwowiona i przemianowana na Wyższą Szkołę Ekonomiczną. Usunięto niektórych zasłużonych profesorów wyznających poglądy „burżuazyjne”. Nastąpiły też zmiany organizacyjne związane $z$ dążeniem do kształcenia w duchu wąskiej specjalizacji zawodowej. Wprowadzono od $1950 \mathrm{r}$. dwustopniowy system studiów: 3-letnie studia I stopnia kończyły się uzyskaniem dyplomu zawodowego, dwuletnie studia II stopnia nadające tytuł magistra były przeznaczone teoretycznie dla najzdolniejszych absolwentów I stopnia, przygotowujących sie na wyższe stanowiska i do pracy naukowej. Systemem tym objęto także słuchaczy już zaawansowanych w studiach. Marian Kanior znalazł się, jako jeden z pierwszych studentów, na nowo utworzonym Wydziale Finansowym (nawiasem mówiąc na tym właśnie wydziale utworzono Katedrę Podstaw MarksizmuLeninizmu), na sekcji rachunkowości. Do końca 1951 r. zaliczył 3 lata studiów, przedstawił pracę dyplomową pt. Rola i formy obrotu bezgotówkowego i 29 lutego 1952 r. złożył egzamin końcowy uzyskując kwalifikacje ekonomisty-księgowego. Ze względu na stan zdrowia nie został powołany do służby wojskowej. Obją go natomiast 3-letni nakaz pracy. Jeszcze pod koniec studiów w kwestionariuszu wypełnianym przez abiturientów deklarował: „ponieważ pociąga mnie praca naukowa, gorąco pragnę dostać się na rok magisterski na WSE przy Katedrze Rachunkowości”, gdyby zaś miał podjąć pracę zawodowa, pragnął zatrudnić się w jakimś banku w Krakowie. I rzeczywiście od 1 kwietnia 1952 r. został skierowany do pracy w Banku Inwestycyjnym.

Podjęte równocześnie starania o przyjęcie na studia II stopnia nie powiodły się. Już 8 stycznia 1952 r. skierował odpowiednie podanie do Ministerstwa, w którym pisał: „Studia te dadzą mi przygotowanie do pracy w szkolnictwie oraz umożliwią pracę naukową która mimo iż jestem tylko 
synem dozorcy była zawsze moim celem i marzeniem". Sprawa potoczyła się zwykłym trybem biurokratycznym: odesłanie podania do komisji wydziałowej WSE, dostarczenie nowych zaświadczeń, ankiety personalnej z życiorysem (pisał tu jeszcze raz, że jego celem $i$ marzeniem jest praca naukowa), nowe podanie, na którym znalazła się adnotacja, że Katedra Rachunkowości nie wysuwa zastrzeżeń. W ankiecie Kanior na pytanie o przynależność organizacyjną mógł podać tylko, że do 1950 r. należał do Bratniej Pomocy Studentów Akademii Handlowej, a potem przez rok do Zrzeszenia Studentów Polskich. Toteż w opinii organizacji studenckich (Komitetu Uczelnianego ZSP i Zarządu Uczelnianego ZMP), wystawionej 25 lutego 1952 r. w związku z podaniem, napisano krótko: „Niezorganizowany. W życiu społecznym naszych organizacji nieznany". To zapewne zaważyło na decyzji. Mimo jego doskonałego "pochodzenia społecznego" Wydziałowa Komisja Kwalifikacyjna nie zakwalifikowała Kaniora na studia magisterskie. W piśmie z 19 marca zawiadomiono go krótko, że jest to uchwała ostateczna.

Pozostawała więc praca w krakowskim oddziale Banku Inwestycyjnego na stanowisku inspektora. Równocześnie powracało, zrodzone jeszcze w dzieciństwie, zainteresowanie sprawami kościelnymi. W czasie podmiejskich wycieczek do Tyńca budziła się fascynacja życiem monastycznym w tamtejszym klasztorze benedyktynów, reaktywowanym ledwie przed kilkunastu laty i mozolnie odbudowywanym, pociagała głębia sprawowanej tam liturgii. Tak rodziło się powołanie kapłańskie i zakonne. Przełomowym momentem - jak wyznawał po latach o. Marian - stały się rekolekcje zamknięte u jezuitów w podkrakowskich Przegorzałach, zakończone 5 marca 1953 r. (ma to może znaczenie symboliczne, że był to dzień śmierci Stalina). Na realizację zamiarów trzeba było jeszcze czekać, gdyż do 31 marca $1955 \mathrm{r}$. obowiazywał nakaz pracy.

Jesienią 1955 r. rozpoczął się w życiu Mariana Kaniora nowy rozdział.

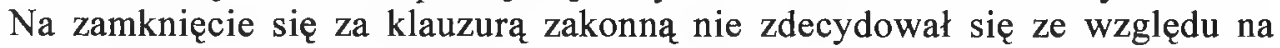
matkę bardzo przywiązaną do jedynaka. Jako 26-letni mężczyzna, z ukończonymi studiami wyższymi i 3-letnia praktyką zawodową, zgłosił się natomiast do seminarium duchownego we Włocławku (w Krakowie i Lublinie nie został przyjęty). Odbył tam studia teologiczne w latach 1955-1961. Dawne zamiłowanie do pracy naukowej rozwinęło się, a pod wpływem wykładów ks. Stanisława Librowskiego, związanego z Włocławkiem historyka, profesora KUL, kierowało się coraz bardziej ku badaniom historycznym. W dniu Zesłania Ducha Świętego, 21 maja 1961 r. otrzymał w katedrze włocławskiej święcenia kapłańskie. Mszę święta prymicyjną odprawił $w$ jednej $z$ najwspanialszych świątyń polskich: kościele Mariackim w Krakowie (jako swym dawnym parafialnym) oraz w kościele w Dziekanowicach, gdzie został ochrzczony.

Po święceniach został skierowany do pracy duszpasterskiej najpierw w małej wsi Przezpolew w powiecie kaliskim, a po pół roku do historycznego miasteczka Kowal (znanego jako miejsce urodzenia Kazimierza Wielkiego) w powiecie włocławskim. Nie przestał myśleć o kontynuowaniu studiów 
ekonomicznych dla uzyskania magisterium. Stało się to możliwe po 1956 r., gdy sytuacja polityczna uległa na tyle zmianie, że można było liczyć na przyjęcie. Ks. Kanior otrzymał zgodę swego biskupa-ordynariusza, Antoniego Pawłowskiego, zaakceptowana przez samego prymasa Wyszyńskiego, na studia w uczelni świeckiej. Odpowiednie podanie złożył wkrótce po święceniach, 27 czerwca 1961 r., a 22 października tegoż roku wysłano zawiadomienie o przyjęciu na studia eksternistyczne II stopnia na Wydziale Produkcji i Obrotu Towarowego Wyższej Szkoły Ekonomicznej w Krakowie. Władze państwowe godziły się na przyjmowanie osób duchownych na studia eksternistyczne, gdzie nie było bliższego kontaktu z młodzieżą. Księdzu Kaniorowi to też odpowiadało, gdyż mógł dalej pracować jako duszpasterz na parafii a tylko dojeżdżać co jakiś czas do Krakowa. Na drugi zaś rok studiów magisterskich (1962/63) otrzymał urlop od biskupa Pawłowskiego. Zamieszkał wtedy w Krakowie, u swoich rodziców i złożył stosowne egzaminy. Pracę magisterską pt. „Problemy równowagi monetarnej gospodarki socjalistycznej we współczesnej polskiej literaturze ekonomicznej" napisał na seminarium prof. Stefana Bollanda, kierownika Katedry Finansów i (do 1962 r.) rektora WSE. Promotor ocenił ją na stopień „plus bardzo dobry”, w recenzji zaś napisał, iż przewyższa wymogi stawiane pracom magisterskim, a jej autor dał dowód uzdolnień naukowych. 28 maja 1963 r. w wyniku zdanego bardzo dobrze egzaminu końcowego ks. Kanior otrzymał tytuł magistra ekonomii. Był to dla niego pierwszy krok na drodze pracy naukowej, do której od dawna tak wytrwale dążył. Miała się ona wszakże zrealizować na innym polu. Przypadek jednak sprawił, że właśnie tu: w Wyższej Szkole Ekonomicznej znalazł się już wówczas blisko osób (choć jeszcze nie nawiązał z nimi bezpośredniego kontaktu), z którymi miał w niedalekiej przyszłości bliżej współpracować w dziedzinie odpowiadajacej jego rzeczywistym zainteresowaniom. Kierownikiem Katedry Historii Gospodarczej WSE był, przybyły niedawno z Torunia, prof. Stanisław Hoszowski a docentem w tej Katedrze - Janina Bieniarzówna, której podpis jako ówczesnego prodziekana Wydziału Ogólnoekonomicznego widnieje i na indeksie, i na dyplomie magisterskim ks. Kaniora.

Po ukończeniu studiów ks. Kanior wrócił do Włocławka i pracował w kurii diecezjalnej jako notariusz. Zetknął się wtedy z przebogatym archiwum diecezjalnym, opracowywanym przez ks. prof. Librowskiego, a przechowującym między innymi również księgi gospodarcze dóbr biskupich z okresu staropolskiego. Zamyślał teraz o doktoracie, w którym mógłby połączyć zainteresowania historyczne $\mathrm{z}$ wykształceniem ekonomicznym. W tym celu nawiązał kontakt $\mathrm{z}$ prof. Hoszowskim. Ten wybitny historyk gospodarczy jeszcze w czasie swej wieloletniej pracy na uniwersytecie toruńskim poznał zbiory włocławskie, a teraz zrealizował edycję naukową lustracji dóbr królewskich $\mathrm{w}$ województwach pruskich $\mathrm{z}$ lat 1565-1624. Interesował się w związku z tym dziejami agrarnymi Pomorza i zamierzał objąc odpowiednimi badaniami majątki kościelne Polski północnej. Nakłaniał też do tych badań swoich uczniów (m.in. pod jego kierunkiem Jerzy Topolski ukończył gruntowną rozprawę o gospodarstwie wiejskim w dobrach arcybiskupstwa 
gnieźnieńskiego, Stefan Cackowski wydał 2-tomową pracę o gospodarstwie wiejskim w dobrach biskupstwa i kapituły chełmińskiej). Przyjmując propozycję ks. Kaniora prof. Hoszowski zasugerował mu na temat rozprawy doktorskiej zajęcie się dobrami biskupstwa włocławskiego na terenie Pomorza. W archiwum diecezjalnym zachowały się cenne materiały do dziejów gospodarczych tych dóbr w XVIII wieku: inwentarze, rachunki itp. pochodzące z trzeciej ćwierci tego stulecia. Ks. Kanior przystapił do żmudnej pracy $\mathrm{z}$ właściwą sobie pracowitością. Nie mając za sobą studiów historycznych korzystał wiele ze wskazówek prof. Hoszowskiego, od którego przejął rzetelność w podejściu do źródeł historycznych i ich interpretacji i wkrótce opanowal warsztat badawczy historyka. Natomiast przygotowanie ekonomiczne ułatwiło mu lepsze rozumienie zjawisk gospodarczych i stosowanie metod statystycznych przy ich prezentacji.

Tymczasem śmierć matki w kwietniu 1965 r. obudziła na nowo pragnienie życia zakonnego i dawny zamiar wstapienia do klasztoru benedyktynów. Wybór zakonu przyjaznego badaniom naukowym a nawet zachęcającego do nich był w pełni uzasadniony. Władze zakonne odniosły się przychylnie do zamysłu kandydata zamierzającego się doktoryzować. Biskup diecezjalny zrazu nie chciał tracić kapłana, którego wykształcił, nie tak dawno wyświęcił i umożliwił mu ukończenie studiów świeckich. Przystał jednak na jego prośbę i w czerwcu 1967 r. wydał odpowiednie zezwolenie. Po wakacjach 1967 r. ks. Kanior zamieszkał w klasztorze tynieckim, na razie jako kandydat do zakonu na prawach gościa, i intensywnie pracował nad ukończeniem rozprawy doktorskiej pt. „Gospodarstwo folwarczne w dobrach pomorskich biskupstwa włocławskiego w drugiej połowie XVIII wieku". Na jej podstawie na Wydziale Filozoficzno-Historycznym Uniwersytetu Wrocławskiego, po zdaniu wymaganych egzaminów (z historii gospodarczej i ekonomii politycznej) oraz obronie pracy, uzyskał 15 stycznia 1969 r. stopień doktora nauk humanistycznych. Promotorem był prof. Hoszowski, recenzentami - prof. Stefan Inglot, podobnie jak Hoszowski jeden z najwybitniejszych przedstawicieli lwowskiej szkoły historii gospodarczej Franciszka Bujaka, a wówczas kierownik Katedry Historii Gospodarczej i Społecznej Uniwersytetu Wrocławskiego, oraz prof. Leonid Żytkowicz z Torunia, autor prac na temat gospodarki wiejskiej w staropolskich dobrach kościelnych.

Teraz dopiero, od 1 lutego 1969 r. ks. dr Kanior odbył nowicjat zakonny, a w dniu swojej patronki NMP Niepokalanej, 8 grudnia 1970 r. złożył w Tyńcu czasowe śluby zakonne (w tym samym dniu w 1973 r. - śluby wieczyste). Znalazł się już na stałe w środowisku, do którego od lat dażył i które dawało mu wymarzone warunki upragnionej pracy naukowej. Pomyślną okolicznością było i to, że przez lata pracował w klasztorze (w 1969 r. podniesionym do rangi opactwa) jako drugi bibliotekarz. Te warunki wykorzystał w pełni dając przykład „benedyktyńskiej” pracowitości. Zajał się zrazu przygotowaniem do druku swojej rozprawy doktorskiej, która zdaniem promotora w pełni na to zasługiwała. Najpierw jeden z wątków wykorzystał na opracowanie obszernego studium pt. „Przemysł dworski w dobrach pomorskich 
biskupstwa włocławskiego w drugiej połowie XVIII w.", opublikowanego w 1973 r. w „Roczniku Gdańskim” (za 1971 r.). Całość dzieła, w zmienionej wersji i ze zmienionym tytułem (, $Z$ badań nad strukturą dochodów wielkiej własności. Dobra pomorskie biskupstwa włocławskiego w II połowie XVIII wieku"), pod postacią obszernej książki zaopatrzonej w liczne tablice statystyczne, ukazała się w 1990 r. w prestiżowej serii monografii Gdańskiego Towarzystwa Naukowego. W recenzji, opublikowanej w warszawskim „Kwartalniku Historii Kultury Materialnej” (R. 40:1992, s. 226-231) napisano, iż praca ,przynosi wiele interesujących ustaleń na temat gospodarstwa wiejskiego, szczególnie zaś ważnej a przez ostatnie lata rzadko badanej kwestii struktury dochodów".

Ojciec dr Kanior doskonalił jeszcze swój warsztat badawczy opanowany przy pracy nad rozprawą doktorską. Służył temu między innymi pobyt na stypendium w roku akademickim 1976/77 w Belgii, na katolickim uniwersytecie w Lowanium (Leuven/Louvain). Teraz jednak zainteresowania o. Kaniora skierowały się na dzieje zakonu, którego stał się członkiem, i oddał się, znów z całym zapałem, badaniom nad historią benedyktynów w Polsce. Trzymał się początkowo najbliższego sobie wieku XVIII i zajał się powstałą wówczas (w 1709 r.) unią wszystkich opactw benedyktyńskich w Koronie i na Litwie. Ta Kongregacja Św. Krzyża nie doczekała się dotąd swojej monografii, a była przecież przejawem odnowy życia mniszego w Rzeczypospolitej. W 1976 r. ukazała się rozprawa o. Kaniora pt. „Powstanie kongregacji benedyktyńskiej św. Krzyża w Polsce" („Analecta Cracoviensia”, 1976), w której na podstawie gruntownej znajomości literatury i źródeł przedstawił historię powstawania kongregacji benedyktyńskich w Europie, starań o powołanie takiej w Polsce, wreszcie jej utworzenia i pierwszych trudności $z$ jej utrzymaniem $w$ pierwszej połowie wieku XVIII. Ta wartościowa rozprawa, zapełniająca pewną lukę w historiografii kościelnej, została także opublikowana po francusku („Jahrbücher für Geschichte Osteuropas”, 1978). Kolejne prace, publikowane w poważnych czasopismach naukowych, poświęcił o. Kanior różnym problemom związanym z działalnością benedyktynów polskich w XVIII stuleciu. W ten sposób został opracowany ustrój prawno-administracyjny opactw benedyktyńskich w Rzeczypospolitej („Studia Historyczne”, 1983) oraz całej Kongregacji Św. Krzyża („Roczniki Teologiczno-Kanoniczne", 1981), organizacja nowicjatu („Wychowanie młodzieży zakonnej...” - „Studia Theologica Varsaviensia”, 1982) oraz studiów filozoficzno-teologicznych u benedyktynów polskich w porównaniu ze studiami w seminariach diecezjalnych i w innych zakonach (., Studia Historyczne", 1981; toż po niemiecku w „Jahrbücher für Geschichte Osteuropas",1982), dbanie o odnowę życia zakonnego przez należyte odprawianie „służby Bożej” czyli mszy świętej i oficjum chórowego („Studia Theologica Varsaviensia", 1982), życie codzienne polskich klasztorów benedyktyńskich („Analecta Cracoviensia", 1981). Do tego doszło obszerne studium dziejów Kongregacji Św. Krzyża w okresie porozbiorowym (1772-1864), kiedy to klasztory benedyktyńskie kasowane były stopniowo we wszystkich zaborach 
aż do zamknięcia w 1864 r. ostatnich trzech: w Pułtusku w Królestwie oraz w Nieświeżu i w Horodyszczu na Litwie („Końcowe dzieje polskiej kongregacji benedyktyńskiej..." - „Analecta Cracoviensia”, 1982). Wszystkie te obszerne udokumentowane źródłowo rozprawy złożyły się na monografię pt. „Polska kongregacja benedyktyńska św. Krzyża (1709-1864)”, niestety nie opublikowaną osobno w całości. Na jej podstawie o. Kanior habilitował się na Wydziale Teologicznym Papieskiej Akademii Teologicznej w Krakowie i uzyskał wyższy stopień naukowy: doktora habilitowanego teologii w zakresie historii Kościoła. Kolokwium habilitacyjne odbyło się 26 maja 1982 r., zatwierdzenie stopnia przez władze kościelne - 8 maja 1985 r. To formalne uznanie o. Kaniora za samodzielnego pracownika naukowego było niejako uwieńczeniem tej mozolnej drogi, która przy pokonywaniu wielu trudności prowadziła od szkółki wiejskiej poprzez maturę w liceum administracyjnym, magisterium z wyższej szkole ekonomicznej, doktoratu z historii gospodarczej na uniwersytecie aż do habilitacji na wydziale teologicznym.

O. dr hab. Marian Kanior stał się uznanym specjalistą od historii zakonu św. Benedykta. Oprócz swego dzieła na temat polskiej Kongregacji Św. Krzyża opublikował jeszcze z tej dziedziny szereg mniejszych prac: syntetyczne ujęcie wyniku swoich badań nad benedyktynami polskimi w XVIII wieku ("Przekrój życia polskich benedyktynów w XVIII wieku" - „Znak", 1980), syntetyczne również omówienie dziejów trzech opactw benedyktyńskich w diecezji krakowskiej: tynieckiego. świętokrzyskiego i sieciechowskiego ("Analecta Cracoviensia" 1994). Zajął się interesującą sprawą fundacji benedyktynów obrządku słowiańskiego przy nie istniejącym dziś kościele św. Krzyża w Krakowie. W pracy zbiorowej na temat życia religijnego w Polsce pod okupacją hitlerowską (pod red. Zygmunta Zielińskiego, 1982) omówił działalność benedyktynów w odrodzonych przed wojną klasztorach w Lubiniu i Tyńcu. Szczególne zainteresowanie poświęcił o. Marian swojemu klasztorowi tynieckiemu. Przygotował więc rozprawę na temat łączący się ściśle z historią polityczną Polski XVIII stulecia: walk konfederatów barskich broniących Tyńca przed wojskami rosyjskimi („Rocznik Krakowski”, 1980). Wyszedł też poza bliski mu wiek XVIII i zajął się historią opactwa tynieckiego od jego kasaty w 1816 r., poprzez próby odnowy aż do powrotu benedyktynów do Tyńca w 1939 r. („Rocznik Krakowski”, 1991), dokładniej zaś, w szeregu artykułów („Studia Theologica Varsaviensia”, 1978; „Revue d'Histoire Ecclésiastique”, 1978; „Analecta Cracoviensia”, 1991) - powrotem benedyktynów do Tyńca w 1939 r. i odbudową klasztoru oraz działalnością przez pięćdziesięciolecie 1939-1989.

Osiagnięcia naukowe o. Kaniora spowodowały, że już w 1984 r. rozpoczałł pracę dydaktyczną na Wydziale Historii Kościoła Papieskiej Akademii Teologicznej, którego organizatorem i dziekanem była prof. Janina Bieniarzówna (równocześnie kierownik Katedry Historii Gospodarczej Akademii Ekonomicznej). 8 maja 1989 r. został mianowany docentem, a 8 maja 1995 r. - profesorem nadzwyczajnym tego wydziału. Kierował najpierw Katedra Historii Teologii a następnie Katedrą Historii Zakonów. Wykładał historię 
duchowości i historię monastycyzmu chrześcijańskiego. Wykłady z ogólnej historii Kościoła prowadził także na studium dla świeckich Wydziału Teologicznego i przejściowo (w latach 1983-1986) w Instytucie Teologicznym Księży Misjonarzy w Krakowie. Wśród słuchaczy znany był ze swej obowiązkowości i punktualności. Na prowadzonym przezeń seminarium gromadziła się niewielka grupa studentów - tych tylko, którzy mogli sprostać stawianym im wysokim wymaganiom pracowitości i rzetelności w badaniach. W ten sposób swoje młodzieńcze plany pracy naukowej o. Marian realizował nie tylko jako badacz penetrujacy archiwa i biblioteki, ale także jako nauczyciel akademicki przekazujący swym uczniom nabytą wiedzę i umiejętności badawcze.

Sam nadal kształcił swój warsztat naukowy i rozszerzał zainteresowania badawcze. Uczestniczył w licznych krajowych i zagranicznych konferencjach naukowych. W pierwszym półroczu $1988 \mathrm{r}$. przebywał jako stypendysta na Katolickim Uniwersytecie Ameryki w Waszyngtonie, a w 1993 r. prowadził badania archiwalne w Wiedniu korzystając ze stypendium fundacji „Janineum". Podjął nowe badania z dziejów duchowości w Polsce, hagiografii i kultu maryjnego. Rozszerzał przy tym zakres chronologiczny swych badań sięgając do średniowiecza. Pisał o bł. Kindze („Studia i materiały do dziejów żup solnych w Polsce" t. 18), o św. Jacku (obszerne studium w znanym wydawnictwie „Święci polscy”, t. 8), przede wszystkim zaś o bł. Salomei. Opracował jej obszerny życiorys (tamże t. 11 oraz osobna publikacja ATK z 1985), pisał też o długich staraniach o beatyfikacje zmarłej w $1268 \mathrm{r}$. księżnej Salomei zakończonych oficjalnym uznaniem jej kultu w $1673 \mathrm{r}$. (w pracy zbior. pt. „Z przeszłości Krakowa”, 1989). Pracą wykraczającą poza dzieje Kościoła polskiego jest studium poświęcone duchowości św. Franciszka Salezego („Ateneum Kapłańskie”, 1990). O. Kanior włączył się także w badania mariologiczne. Brał udzial w polskich i zagranicznych kongresach mariologicznych. Publikował prace dotyczące kultu maryjnego u benedyktynów polskich na przełomie XVIII i XIX wieku (w pracy zbior. pt. „Niepokalana. Kult Matki Bożej na ziemiach polskich w XIX wieku", 1988) i po II Soborze Watykańskim (materiały VI ogólnopolskiego kongresu maryjnego i mariologicznego w Częstochowie w $1990 \mathrm{r}$. oraz po angielsku w materiałach z XI kongresu mariologicznego w Huelva w Hiszpanii w 1992 r.), a także o sanktuariach Matki Boskiej w klasztorach benedyktyńskich: w Staniątkach („Analecta Cracoviensia”, 1992), w Górce Duchownej (w pracy zbior. pt. „Klasztor w społeczeństwie średniowiecznym i nowożytnym”, 1996), w Sierpcu (w pracy zbior. pt. „Benedyktyńska praca”, 1998).

Wybór kardynała Karola Wojtyły na papieża a następnie różne rocznice jego posługiwania stały się okazją do bardzo wielu sympozjów naukowych i publikacji. O. Kanior włączył się w ten nurt badawczy i to bardzo ambitnie. Na 10-lecie wyboru papieskiego ogłosił obszerne i opatrzone precyzyjnym aparatem przypisów studium o kulcie maryjnym w działalności duszpasterskiej Karola Wojtyły (w pracy zbior. pt. „Karol Wojtyła jako biskup krakowski”, 1988). Z okazji zaś sympozjum naukowego zorganizowanego w $1996 \mathrm{r}$. 
przez Papieską Akademię Teologiczną na 50-lecie święceń kapłańskich Jana Pawła II przygotował syntetyczne a przy tym szczegółowo udokumentowane opracowanie działalności Karola Wojtyły jako metropolity krakowskiego (w pracy zbior. pt. „Kapłaństwo służebne w życiu i nauczaniu Jana Pawła II”, 1997). Znalazło się tu omówienie wizytacji biskupich, organizacji kurii metropolitalnej, koronacji obrazów Matki Bożej, działalności seminarium duchownego i Wydziału Teologicznego, organizacji sesji naukowych itd.

W związku z przypadającym w 2000 r. 600-leciu odnowienia Akademii Krakowskiej, a jeszcze wcześniej powstania jego Wydziału Teologicznego podjęto szereg inicjatyw wydawniczych. Wiele uwagi poświęcono staraniom o przygotowanie poważnej, stosownie do znaczenia tego Wydziału, monografii historycznej. O. Kanior uczestniczył aktywnie w tych zabiegach biorąc na siebie trud napisania części obejmującej lata 1780-1880, tj. stulecie od reformy Kołłątajowskiej do reorganizacji Wydziału przywracającej mu wysoką rangę naukową, dokonanej dekretem cesarskim. Wymagało to zapoznania się z nowego typu źródłami i z nową problematyką. Już 11 stycznia 1993 r. wygłosił w katedrze wawelskiej uroczysty wykład (w ramach cyklu wykładów przygotowujących jubileusz erygowania Wydziału w 1397 r.) pt. "Dzieje Wydziału Teologicznego Uniwersytetu Jagiellońskiego w latach 1780-1880" (opublikowany w „Analecta Cracoviensia”, 1993). Następnie, w miarę postępujących badań, publikował artykuły omawiające kolejne odcinki chronologiczne dziejów Wydziału: w przededniu reformy Kołłątajowskiej (,Analecta Cracoviensia”, 1996), w czasie tej reformy („Rocznik Krakowski”, 1993), w pierwszym okresie panowania austriackiego od 1795 do 1809 r. (,Analecta Cracoviensia”, 1995), w dobie Księstwa Warszawskiego („Folia Historica Cracoviensia” 1996), w Wolnym Mieście Krakowie („Saeculum Christianum", 1994). Osobno opracował, także statystycznie, stan studentów teologii w okresie Wolnego Miasta („Folia Historica Cracoviensia”, 1996) oraz w czasach germanizacji i początków autonomii galicyjskiej, tj. w latach 1848-1880 („Prace Naukowe Wyższej Szkoły Pedagogicznej w Częstochowie. Zeszyty Historyczne", 1997). Zwieńczeniem tych badań stało się opracowanie całościowe pod postacią 420-stronicowej monografii pt. „Wydział Teologiczny w dziejach Uniwersytetu Jagiellońskiego (1780-1880)" (1998), stanowiącej tom VIII jubileuszowych „Studiów do dziejów Wydziału Teologicznego Uniwersytetu Jagiellońskiego". To nowe dzieło, wynik badań w archiwach krakowskich i wiedeńskich, zaopatrzone w liczne tablice statystyczne, ilustracje i bogatą dokumentację źródłową odznacza się - jak inne prace o. Kaniora - gruntownością ujęcia i przejrzysta kompozycją.

W swej długoletniej pracy dydaktycznej jako profesor historii Kościoła o. Marian Kanior skupiał się najchętniej na dziejach życia zakonnego. Jako benedyktynowi najbliższe mu były zakony mnisze. Ukoronowaniem tej pracy - jak to bywa u zasłużonych profesorów - ma być pozostawienie po sobie, pod postacią podręcznika akademickiego, wielkiego ujęcia syntetycznego dziejów monastycyzmu zarówno w Kościele zachodnim jak i wschodnim. Tak zaczęła powstawać obliczona na 3 tomy „Historia monastycyzmu chrze- 
ścijańskiego". W 1993 r. ukazał się tom pierwszy tego dzieła z podtytułem „Starożytność", obejmujący wieki III-VIII. Tomy następne są przygotowywane.

W pisarstwie naukowym o. Mariana Kaniora widać szerokość tematyczną zainteresowań $\mathrm{i}$ - co się z tym wiąże - opanowanie różnorodnych metod badawczych. Dlatego właśnie to zaskakujące na pozór połączenie różnych bardzo dziedzin historii nie groziło dyletantyzmem, lecz przeciwnie - pozwalało na pogłębione ujęcie, kiedy na przykład przy opracowywaniu historii opactw benedyktyńskich o. Kanior potrafił z łatwością omawiać zarówno gospodarkę, jak i duchowość zakonną. Poruszał się także swobodnie w różnych epokach: od starożytności i średniowiecza po czasy nam współczesne.

Benedyktyńska zasada modlitwy i pracy realizowała się w całej drodze życiowej ojca Mariana, prowadzacej od wiejskiej chaty do czcigodnego opactwa w Tyńcu. Znalazła swą pełnię w radosnym trudzie badań bibliotecznych i archiwalnych nad odsłanianiem przeszłości i we wzniosłej liturgii odprawianej w benedyktyńskim klasztorze. Ale zasadę tę można odczytać też w twórczości naukowej ojca Mariana: badał zarówno znojną pracę na roli chłopów pomorskich $\mathrm{w}$ dobrach biskupstwa włocławskiego, intelektualną pracę profesorów Akademii Krakowskiej, jak i duchowość chrześcijańską anachoretów, mnichów i świętych.

30 listopada 1998 r. państwowa Centralna Komisja do Spraw Tytułu Naukowego i Stopni Naukowych, na wniosek Rady Naukowej Episkopatu zatwierdziła nadanie o. Marianowi Kaniorowi OSB tytułu profesora nauk teologicznych. W dniu swych 70. urodzin o. Marian jest nadal w pełni aktywnym badaczem naukowym i nauczycielem akademickim, profesorem wykładajacym na Wydziale Historii Kościoła Papieskiej Akademii Teologicznej, kierownikiem Katedry Historii Zakonów. 